\title{
Body mass index (BMI) and alpha- fetoprotein (AFP) level correlate with the severity of HCV-induced fibrosis in a cohort of Egyptian patients with chronic HCV
}

Amal Ahmed Mohamed ${ }^{1 \dagger}$, Amr Ali Hemeda ${ }^{2 \dagger}$, Ramy Karam Aziz ${ }^{3}$, Mohamed Salaheldin Abdel-Hakeem ${ }^{3 *}$ and Marwa Ali-Tammam ${ }^{2 *}$ id

\begin{abstract}
Background: Viral hepatitis is the seventh leading cause of mortality globally, and half of this mortality is attributed to hepatitis $\mathrm{C}$ virus (HCV). Egypt has the highest HCV prevalence worldwide, with an estimated $14.7 \%$ of the population being HCV-positive. HCV infection is the primary cause of liver fibrosis, cirrhosis, and hepatocellular carcinoma. Liver fibrosis varies in severity during chronic HCV infection, and 10-20\% of chronic hepatitis C (CHC) patients with severe fibrosis develop cirrhosis. The goal of this work was to assess the clinico-demographic predictors of severity of HCV-induced fibrosis in a cohort of Egyptian patients.

Results: A cohort of Egyptian patients with chronic HCV genotype 4a infection showed significant association between severe fibrosis stages and obesity, represented by a higher body mass index (BMI), low albumin level, high alpha-fetoprotein (AFP) level, low thyroid-stimulating hormone (TSH) level, and high alkaline phosphatase (ALP) level. Multivariate analysis delineated BMI, TSH, and ALP as independent significant variables that could predict the risk of fibrosis severity in HCV infections.

Conclusion: This study argues in favor of using the biomarker profile of $\mathrm{CHC}$ patients infected with HCV genotype $4 a$ to identify patients at higher risk of developing severe fibrosis, which is a necessary first step towards precision medicine via patient stratification.
\end{abstract}

Keywords: Liver, Hepatitis, Virology, Genetics, Multivariate

\footnotetext{
* Correspondence: mohamed.salaheldin@pharma.cu.edu.eg;

marwa.ali@fue.edu.eg

AAH is the co-first author for this work.

${ }^{3}$ Department of Microbiology and Immunology, Faculty of Pharmacy, Cairo

University, Cairo, Egypt

${ }^{2}$ Department of Microbiology and Immunology, Faculty of Pharmaceutical

Sciences and Pharmaceutical Industries, Future University in Egypt, Cairo,

Egypt

Full list of author information is available at the end of the article
}

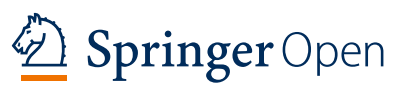

(c) The Author(s). 2020 Open Access This article is licensed under a Creative Commons Attribution 4.0 International License which permits use, sharing, adaptation, distribution and reproduction in any medium or format, as long as you give appropriate credit to the original author(s) and the source, provide a link to the Creative Commons licence, and indicate if changes were made. The images or other third party material in this article are included in the article's Creative Commons licence, unless indicated otherwise in a credit line to the material. If material is not included in the article's Creative Commons licence and your intended use is not permitted by statutory regulation or exceeds the permitted use, you will need to obtain permission directly from the copyright holder. To view a copy of this licence, visit http://creativecommons.org/licenses/by/4.0/. 


\section{Background}

Viral hepatitis is the seventh leading cause of mortality globally [1], and half of this mortality is attributed to hepatitis $\mathrm{C}$ virus (HCV). Almost 71 million individuals are estimated to be infected worldwide, with $\sim 750,000$ new infections occurring annually [2]. HCV infection is the primary cause of liver fibrosis, cirrhosis, and hepatocellular carcinoma (HCC) [3].

Egypt has the highest prevalence of HCV infection worldwide, with an estimated $14.7 \%$ of the population being $\mathrm{HCV}$-positive $[4,5]$. Genotype $4 \mathrm{a}$ is the most prevalent genotype in Egypt. The main cause of this endemic is attributed to mass parenteral antischistosomal therapy campaigns in the 60 s to 80 s of the twentieth century [6].

During the acute phase of HCV infection, defined as the first six months post-infection, only $20 \%$ of patients spontaneously clear the virus [7]. However, in $80 \%$ of cases, the immune system is unable to eradicate HCV during the acute phase and $\mathrm{HCV}$ persists, leading to chronic hepatitis $\mathrm{C}(\mathrm{CHC})$ infection [8], which may contribute to the development of liver fibrosis, cirrhosis, and HCC as complications [9]. Several factors influence the progression of liver diseases; the most important of which is the extent of intrahepatic inflammation caused by HCV [10].

Genetic diversity of the virus and its rapid mutation rate may allow HCV to escape immune recognition [11]. In case of $\mathrm{CHC}$, most patients are asymptomatic and may have nonspecific symptoms such as fatigue, arthralgia, or myalgia [12].

Most of HCV infection cases will have persistently elevated liver enzymes in further follow-up [13]. However, the transaminase level may even remain normal or moderately increased [14]. Their level may vary significantly over the natural history of $\mathrm{CHC}$ and most of the patients may have only slight elevation of transaminases $[15,16]$.

$\mathrm{HCV}$ infection can also cause liver cell failure or HCC (approximately 2 to $4 \%$ per year) [17]. However, there are a number of factors that affect liver disease progression, and it is important to understand the natural history of $\mathrm{HCV}$ to be able to take correct decisions to reduce disease progression rates [18].

Structural liver damage, also known as fibrosis, is variable in chronic HCV infection. In mild cases, fibrosis is limited to the portal and peripheral areas, whereas more advanced fibrosis extends from one portal area to cirrhosis, which develops in approximately $10-20 \%$ of $\mathrm{CHC}$ individuals over 20 years [19]. Patients with $\mathrm{CHC}$ infection display the typical natural history of liver fibrosis, starting from the early stages of fibrosis, and in severe cases ending in liver cirrhosis [20,21]. Fibrosis is one of the main prognostic factors that is correlated with the risk of developing liver cirrhosis. The study of demographic data and common clinical parameters is considered a good tool to indicate the possibility of fibrosis severity without any invasive intervention.
In the present study, we aimed to evaluate and determine the potential association between patients' demographics and clinical parameters on the degree of fibrosis severity in a cohort of Egyptian patients.

\section{Methods \\ Study cohort \\ Subjects}

One hundred adult Egyptian patients, with laboratoryconfirmed chronic infections with hepatitis $\mathrm{C}$ virus genotype 4 , were enrolled in the present study. The 100 patients included 34 females and 66 males, aged 20-60 years.

Blood samples were collected from patients diagnosed at National Hepatology \& Tropical Medicine Research Institute, Cairo, Egypt within the period from August 2017 until December 2017.

A written informed consent was obtained from each participant, and all patients were fully informed concerning the nature of the disease and the diagnostic procedures involved.

\section{Inclusion criteria}

Patients with the following characteristics were included in the study: adult, male or female (18-60 years old), chronic HCV infection (more than a 6-month duration), elevation of serum aminotransferases (AST and ALT) levels, evidence of chronic hepatitis in liver biopsy, not previously treated with any antiviral drugs, cessation of all immune modulating therapy, and HBsAg-negative.

\section{Exclusion criteria}

Patients with the following characteristics: co-infection with $\mathrm{HBV}$, decompensated liver cirrhosis, autoimmune liver disease, chronic renal disease, ischemic cardiovascular disease, antiviral or immunosuppressive therapy within the last 6 months, pregnancy and/or breastfeeding, uncontrolled diabetes mellitus or hypertension, and alcoholism were excluded.

\section{Groups}

The patients were classified into two groups according to the stage of liver fibrosis identified by liver biopsy and FibroScan according to Ishak's scoring system [22]:

- Group 1 was defined as "mild fibrosis patients" (mild group): from F1-F3.

- Group 2 was defined as "severe fibrosis patients" (severe group): from F4-F6.

\section{Blood sample collection}

Five milliliters peripheral blood sample was withdrawn from patients. In each sample, two milliliters were withdrawn into an EDTA tube for later DNA extraction, while $3 \mathrm{~mL}$ was taken in a plain tube for serum 
separation that was used to carry out all serological markers for $\mathrm{HCV}, \mathrm{HBV}$, and standard laboratory tests.

\section{Standard laboratory tests Liver function tests}

Determination of prothrombin time and concentration, serum bilirubin (direct and total), serum albumin, aspartate transaminase (AST), alanine transaminase (ALT), alphafetoprotein (AFP), complete blood picture (CBC), and alkaline phosphatase (ALP) assay were performed on all samples.

\section{Markers of hepatitis virus}

HBsAg was detected using ELISA Murex HBsAg version 3 commercially available kit (Diasorin $^{\circ}$, UK), and Anti$\mathrm{HCV}$ was assessed by ELISA Murex Anti-HCV version 4 kit (Diasorin $\left.{ }^{\circ}, \mathrm{UK}\right)$. All procedures were done according to manufacturer instructions.

\section{HCV-RNA titer}

HCV-RNA titer was measured by real-time PCR using (Stratagene, Model: MX 3000PTM) equipment.

\section{Thyroid function tests}

T3, T4, and TSH levels were determined using IMMULITE 1000 immunoassay system (Siemens ${ }^{\bullet}$ Healthineers) for all patients.

\section{Random blood glucose level}

It was determined using glucose assay kit (Abcam $\left.{ }^{\circ}, \mathrm{UK}\right)$ for all patients.

\section{Statistical analyses}

All statistical analyses were performed in the SPSS Statistical software package (v. 20) for Windows (SPSS, Chicago, IL). The graphs were plotted by GraphPad Prism 7 (GraphPad Software, San Diego, CA).

Quantitative data were summarized as mean, standard deviation, median, minimum, and maximum. Frequency (count) and relative frequency (percentage) were used to summarize categorical data. Non-parametric quantitative variables were compared by the Mann-Whitney test. Parametric quantitative variables were compared by the Student $t$ test. For interpretation of results, $p$ values < 0.05 were considered statistically significant.

Univariate and multiple binary logistic regression analyses were completed to detect predictors associated with the risk of severe fibrosis. The significant data in the univariate analysis were further analyzed by multiple analysis to determine the independent variables that affected the fibrosis severity.

\section{Results}

Patient demographics and laboratory characteristics Study cohort

The 100 adult liver fibrotic patients chronically infected with hepatitis $\mathrm{C}$ virus (HCV) were categorized into two groups: group 1, $59 \mathrm{HCV}$ patients with mild stages of fibrosis (thereafter, indicated as the mild group), and group 2, $41 \mathrm{HCV}$ patients with severe stages of fibrosis (thereafter, indicated as the severe group).

The two groups were matched for the main demographic features, including gender and age distribution, since the gender distribution and the mean age were not significantly different between the two groups $(p>0.05)$ (Table 1$)$.

The mean BMI of the mild group was $25.80 \pm 9.03 \mathrm{~kg} /$ $\mathrm{m}^{2}$ and that of the severe group was $31.78 \pm 8.84 \mathrm{~kg} / \mathrm{m}^{2}$, with a significant difference between the two groups ( $p$ $<0.001$ ) (Fig. 1).

\section{Association between clinical parameters and severity of fibrosis:}

Numerous clinical parameters were available for the patients in the study cohort. We performed statistical analysis to identify parameters that could be associated with the degree of fibrosis (Table 2).

Comparing the laboratory investigation results revealed a significant difference in the levels of serum albumin (AL) $(p=0.008)$, alpha-fetoprotein (AFP) $(p=$ $0.033)$, thyroid-stimulating hormones (TSH) $(p=0.022)$, and alkaline phosphatase (ALP) $(p=0.037)$ between both groups (Fig. 2). No significant difference was found in the levels of aspartate aminotransferase (AST), alanine aminotransferase (ALT), total bilirubin (TBIL), direct bilirubin (DBIL), blood glucose (BG), hemoglobin ( $\mathrm{Hb}$ ), creatinine $(\mathrm{Cr})$, nor the platelet count and white blood cell (WBC) count ( $p>0.05$ for all parameters) between both groups.

\section{Univariate and multivariate analyses for the parameters affecting fibrosis severity}

Analysis of univariate and multivariate logistic regression were used to determine the factors that may be associated with severe fibrosis in $\mathrm{CHC}$ patients infected with $\mathrm{HCV}$ genotype 4a (Table 3). In the univariate analysis, BMI, albumin, TSH, and ALP were designated as significant predictors associated with the severe fibrosis in our study cohort. On conducting multivariate analysis, BMI, TSH, and ALP were designated as independent significant variables that could be used as predictors for the risk of fibrosis severity in $\mathrm{HCV}$ infections.

\section{Discussion}

Chronic HCV is a major cause of liver fibrosis leading to cirrhosis and hepatocellular carcinoma [23, 24]. The rate of progression of fibrosis is highly variable, where 
Table 1 Patients' demographic characteristics

\begin{tabular}{llll}
\hline $\begin{array}{l}\text { Demographic } \\
\text { data }\end{array}$ & $\begin{array}{l}\text { Mild group }(N=59) \\
\text { No. }\end{array}$ & $\begin{array}{l}\text { Severe group }(N=41) \\
\text { No. }\end{array}$ & $\begin{array}{l}\text { Test of sig. } \\
\text { value }\end{array}$ \\
\hline $\begin{array}{l}\text { Gender } \\
\text { Males }\end{array}$ & 37 & 29 & Chi-square test \\
Females & 22 & 12 & 0.405 \\
$\begin{array}{l}\text { Age (years) } \\
\text { Mean } \pm \text { SD }\end{array}$ & $41.0 \pm 8.0$ & $38.95 \pm 7.82$ & Student's $t$ test \\
\hline
\end{tabular}

The $p$ value for comparisons between mild and severe fibrosis groups

progression to cirrhosis ranges from 10 to 30 years [25, 26]. The prevalence of chronic HCV infection in Egypt is $\sim 14.8 \%$ [2], underscoring importance to highlight various parameters associated with fibrosis severity in chronic HCV Egyptian patients. This study identified significant associations between severe fibrosis and high BMI, low albumin level, high AFP level, low TSH level, and high ALP level. Multivariate analysis revealed BMI, TSH, and ALP as independent significant variables associated with severe fibrosis in chronic infection with HCV genotype 4a.

Our results showed that obesity is a factor associated with increased risk of $\mathrm{HCV}$-induced liver fibrosis. This finding agrees with several previous studies [27-32]. However, this BMI association with risk is not unchallenged, as a previous study reported no significant difference between BMI and severe fibrosis stages [33]. It is possible that, in the latter study, other confounding factors had major effects or that the number of subjects did not offer sufficient statistical power to resolve the BMI contribution [33].
Albumin is the main protein circulating in the blood, yet only formed by the liver [34]. The lower albumin level in patients with severe fibrosis is in accordance with several studies that reported similar results [35-39]. Our results revealed that with increasing $\mathrm{HCV}$ severity, the patients were at high risk for impairment in the thyroid function with decreasing in the activity of the thyroid gland (hypothyroidism), a finding that agrees with Metwalley et al. [40]. Similarly, Rodríguez-Torres et al. [41] and Chang et al. [42] reported that patients with severe fibrosis require thyroid treatment.

Serum AFP is a fetal glycoprotein. It is a widely used marker for HCC [43]. Our result was congruent with two published studies [44, 45], but not with Dayan et al. [46], who suggested there was no association between AFP level and HCV fibrosis progression. They thought that it was due to the limited number of patients.

The ALP level decreased in the severe group, in agreement with Das et al. [47]; however, results reported by Ijaz et al. [48], Attallah et al. [49], and Wai et al. [50]

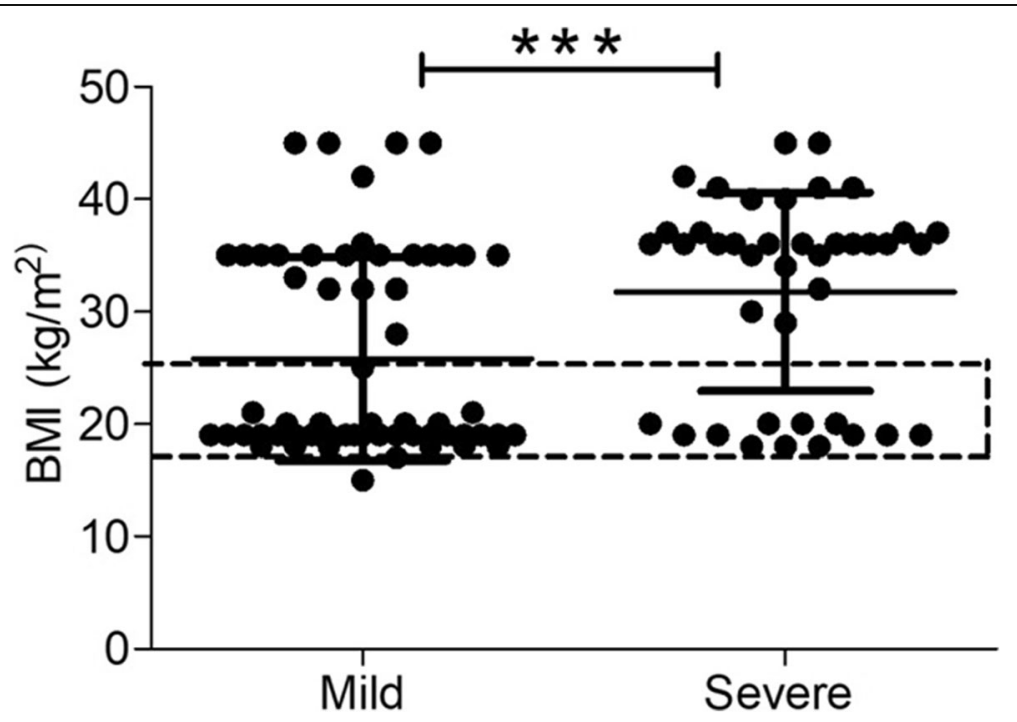

Fig. 1 Comparison of body mass index (BMI) between the two studied groups. BMl of patients from the mild group ( $N=59)$ and severe group $(N=41)$. The median and interquartile range is shown with horizontal lines. The dashed box represents the normal range for BMI in healthy individual $\left(18.9-25 \mathrm{~kg} / \mathrm{m}^{2}\right)$. ${ }^{* *} p<0.001$ 
Table 2 Results of laboratory investigations

\begin{tabular}{|c|c|c|c|}
\hline \multirow[t]{2}{*}{ Laboratory investigations } & Mild group $(\boldsymbol{N}=59)$ & Severe group $(\boldsymbol{N}=41)$ & \multirow{2}{*}{$\begin{array}{l}\text { Chi- } \\
\text { square } \\
\boldsymbol{p} \\
\text { value }\end{array}$} \\
\hline & Mean \pm SD & Mean \pm SD & \\
\hline Albumin $(\mathrm{g} / \mathrm{dL})$ & $3.96 \pm 0.37$ & $3.74 \pm 0.42$ & $0.008^{* *}$ \\
\hline Alpha-fetoprotein (ng/ml) & $13.05 \pm 5.87$ & $14.07 \pm 18.34$ & $0.033^{*}$ \\
\hline TSH (IU/L) & $3.70 \pm 0.71$ & $3.34 \pm 0.82$ & $0.022^{*}$ \\
\hline ALP (IU/L) & $136.44 \pm 42.97$ & $113.61 \pm 53.61$ & $0.037^{*}$ \\
\hline AST (IU/L) & $86.63 \pm 60.22$ & $92.29 \pm 53.72$ & 0.334 \\
\hline ALT (IU/L) & $75.85 \pm 48.26$ & $68.07 \pm 33.47$ & 0.725 \\
\hline Total Bilirubin (mg/dL) & $1.07 \pm 0.37$ & $0.99 \pm 0.46$ & 0.125 \\
\hline Direct bilirubin (mg/dL) & $0.24 \pm 0.14$ & $0.27 \pm 0.22$ & 0.478 \\
\hline Blood glucose (mg/dL) & $98.92 \pm 16.02$ & $97.46 \pm 16.43$ & 0.660 \\
\hline Hemoglobin $(\mathbf{H b})(\mathrm{g} / \mathrm{dL})$ & $11.91 \pm 1.75$ & $11.55 \pm 1.80$ & 0.318 \\
\hline Creatinine (mg/dL) & $0.97 \pm 0.16$ & $1.0 \pm 0.19$ & 0.847 \\
\hline Platelet $\left.\left(10^{3} / \mu \mathrm{L}\right)\right)$ & $271.08 \pm 69.61$ & $286.41 \pm 75.42$ & 0.450 \\
\hline WBCs (cells $/ \mathrm{mm}^{3}$ ) & $7938.59 \pm 1696.06$ & $7582.90 \pm 1803.64$ & 0.150 \\
\hline
\end{tabular}

Chi-square $p$ values for comparisons between mild and severe groups: ${ }^{*} p<0.05,{ }^{* *} p<0.01$, and ${ }^{* * *} p<0.001$

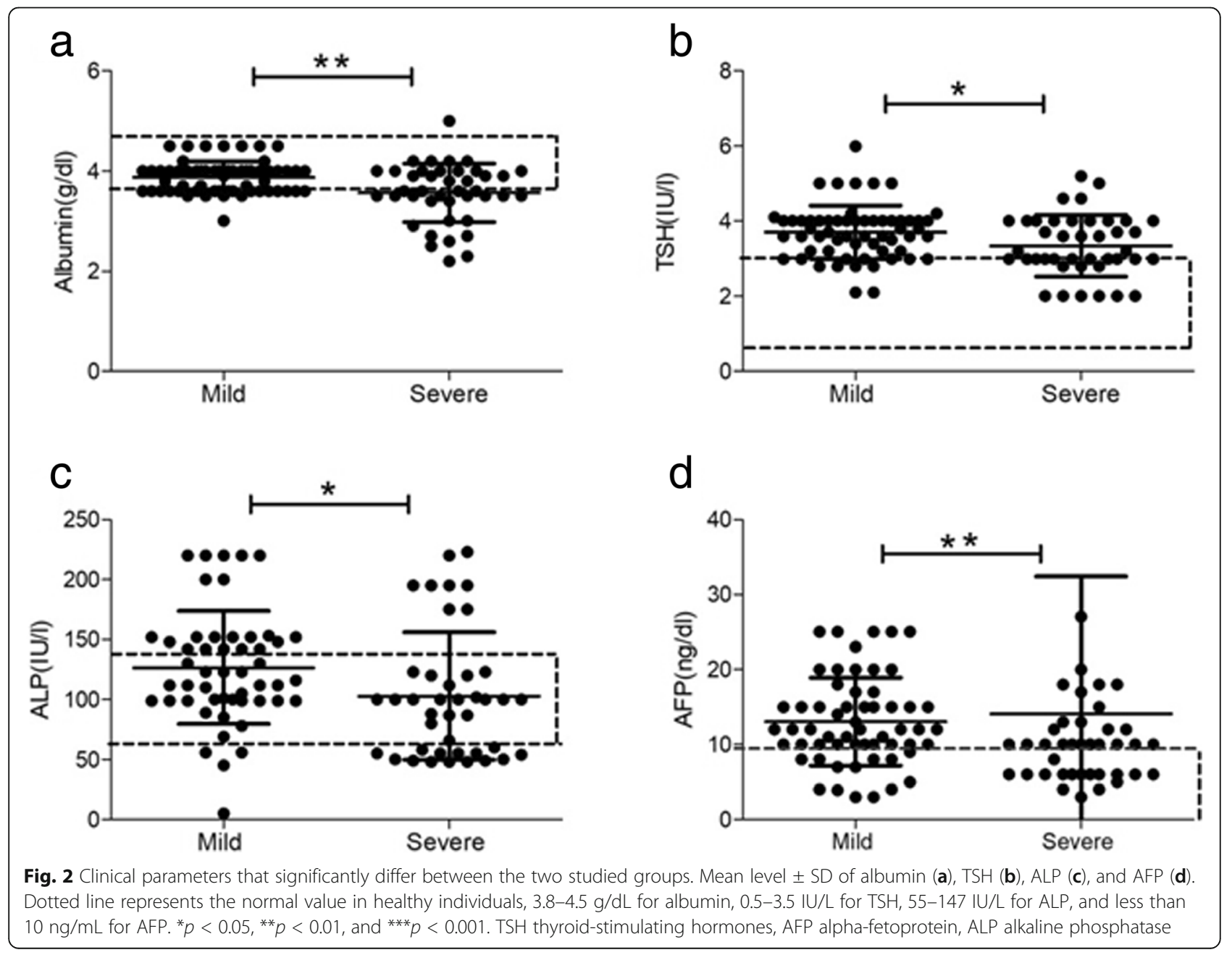


Table 3 Logistic regression analysis of clinical parameters associated with the degree of liver fibrosis in patients infected with HCV genotype $4 a$

\begin{tabular}{|c|c|c|c|c|}
\hline & \multicolumn{2}{|c|}{ Univariate analysis } & \multicolumn{2}{|c|}{ "Multivariate analysis } \\
\hline & $\boldsymbol{p}$ value & OR $(95 \% \mathrm{Cl})$ & $p$ value & OR $(95 \% \mathrm{Cl})$ \\
\hline Sex (male) & 0.240 & $1.437(0.785-2.630)$ & & \\
\hline Age (years) & 0.074 & 0.967 (0.933-1.003) & & \\
\hline $\mathrm{BMI}\left(\mathrm{kg} / \mathrm{m}^{2}\right)$ & $<0.001^{* * *}$ & $1.074(1.040-1.110)$ & $<0.001^{* * *}$ & $1.125(1.070-1.183)$ \\
\hline AST (IU/L) & 0.493 & $1.002(0.997-1.007)$ & & \\
\hline $\mathrm{ALT}(\mathrm{IU} / \mathrm{L})$ & 0.212 & $0.995(0.988-1.0003)$ & & \\
\hline Albumin (g/dL) & $<0.001^{* * *}$ & $0.237(0.107-0.523)$ & 0.160 & $0.401(0.112-1.436)$ \\
\hline Total bilirubin (mg/dL) & 0.184 & $0.614(0.299-1.261)$ & & \\
\hline Direct bilirubin (mg/dL) & 0.304 & $2.320(0.467-11.537)$ & & \\
\hline Blood glucose (mg/dL) & 0.530 & $0.994(0.977-1.012)$ & & \\
\hline $\operatorname{AFP}(\mathrm{ng} / \mathrm{mL})$ & 0.573 & $1.006(0.984-1.029)$ & & \\
\hline $\mathrm{Hb}(\mathrm{g} / \mathrm{dL})$ & 0.155 & $0.889(0.756-1.045)$ & & \\
\hline Platelet $\left(10^{3} / \mu \mathrm{L}\right)$ & 0.139 & $1.003(0.999-1.007)$ & & \\
\hline WBCs (cells/mm³) & 0.155 & $1.000(1.0-1.0)$ & & \\
\hline TSH (IU/L) & $0.002^{* *}$ & $0.523(0.349-0.783)$ & $0.005^{* *}$ & $0.381(0.193-0.751)$ \\
\hline Creatinine (mg/dL) & 0.371 & $2.114(0.411-10.873)$ & & \\
\hline ALP (IU/L) & $0.004^{* *}$ & $0.990(0.983-0.997)$ & $<0.001^{* * *}$ & $0.982(0.974-0.991)$ \\
\hline
\end{tabular}

The $p$ value of the comparison between mild and severe groups

\#All variables with $p<0.05$ were included in the multivariate analysis

${ }^{*} p<0.05,{ }^{* *} p<0.01$, and ${ }^{* * *} p<0.001$. All $p$ values $<0.05$ are shown in bold

were different. These studies suggested that lower viral load, higher bilirubin, and high levels of ALP and AST were associated with more severe fibrosis. They revealed that the higher levels of ALP are usually associated with liver metastasis, extra-hepatic bile obstruction, primary biliary cirrhosis, intrahepatic cholestasis, infiltrative liver disease, hepatitis, and cirrhosis.

Regarding age as a factor, our results agrees with several studies [51-54]. Massard et al. [30] reported that older age was associated with an increased risk of HCVassociated liver diseases. On another front, Gicquelais et al. [55], Espinosa et al. [56], and Prussing et al. [57] reported that $\mathrm{HCV}$ incidence has changed dramatically over the past years, with significant increase in the incidence of $\mathrm{HCV}$ among young people aged around 15-29 years.

Regarding the patients' gender, our results were in accordance with Narciso-Schiavon et al. [58]. However, there was a slight increase in the percentage of males especially in the severe group, in accordance with studies $[30,51,52]$. This issue remains controversial, as laboratory analysis showed no significant difference between the studied groups, in accordance with several studies [59-61], while other studies contradict our observations [62-65]. It is possible, though, that the overrepresentation of male subjects relates to HCV infection in general [52] and is not associated with a certain complication or its severity.

\section{Conclusion}

In conclusion, Egyptian patients with HCV type 4 infection showed significant association between severe fibrosis stages and high BMI (obesity), low albumin level, high AFP level, low TSH level, and high ALP level. In the univariate analysis, BMI, albumin, TSH, and ALP were designated as significant predictors associated with the severe fibrosis in HCV Egyptian patients. In the multivariate analysis, BMI, TSH, and ALP were designated as independent significant variables that could be used as predictors for the risk of fibrosis severity in $\mathrm{HCV}$ infections.

This study may direct practitioners and clinicians to determine the patient biomarker profiles which in turn defines who is at high risk for developing severe fibrosis and who is protecting from severe fibrosis. Such patient stratification step is pivotal to any attempt for adopting a precision medicine approach towards managing and prioritizing $\mathrm{HCV}$ cases.

\section{Abbreviations}

AFP: Alpha-fetoprotein; ALP: Alkaline phosphatase; ALT: Alanine transaminase; AST: Aspartate transaminase; BMl: Body mass index; CHC: Chronic hepatitis C; HBsAg: Hepatitis B surface antigen; HBV: Hepatitis B virus;

HCC: Hepatocellular carcinoma; HCV: Hepatitis C virus; PAT: Parenteral antischistosomal therapy; TSH: Thyroid stimulating hormones; WBC: White blood cell

\section{Acknowledgments}

Not applicable 


\section{Authors' contributions}

A.A.H., R.K.A., M.S.A., and M.A.T. conceived and designed the experiments. A.A.M. provided the samples and clinical information. A.A.H. performed the statistical analysis and prepared the figures. A.A.H., M.S.A., and M.A.T. wrote the manuscript, and R.K.A. critically read the manuscript. All authors read and approved the manuscript.

\section{Funding}

This research did not receive any funding.

\section{Availability of data and materials}

All data and materials are available upon request.

\section{Ethics approval and consent to participate}

The study protocol was approved by the Research Ethics Committee, Faculty of Pharmacy, Cairo University, Egypt (REC-FOPCU), under the protocol serial number: MI (2038)

A written informed consent was obtained from each participant, and all patients were fully informed concerning the nature of the disease and the diagnostic procedures involved.

\section{Consent for publication}

A consent for publication was obtained from all participants.

\section{Competing interests}

The authors declare that they have no competing interests.

\section{Author details}

'Department of Biochemistry and Molecular Biology, National Hepatology and Tropical Medicine Research Institute, Cairo, Egypt. ${ }^{2}$ Department of Microbiology and Immunology, Faculty of Pharmaceutical Sciences and Pharmaceutical Industries, Future University in Egypt, Cairo, Egypt. ${ }^{3}$ Department of Microbiology and Immunology, Faculty of Pharmacy, Cairo University, Cairo, Egypt.

Received: 15 July 2020 Accepted: 17 August 2020

Published online: 24 October 2020

\section{References}

1. Stanaway JD, Flaxman AD, Naghavi M et al (2016) The global burden of viral hepatitis from 1990 to 2013: findings from the Global Burden of Disease Study 2013. Lancet Lond Engl 388:1081-1088. https://doi.org/10. 1016/50140-6736(16)30579-7

2. Elghitany I (2019) Hepatitis C virus infection in Egypt: current situation and future perspective. J High Inst Public Health 49:1-9. https://doi.org/10. 21608/jhiph.2019.29460

3. Mohd Hanafiah K, Groeger J, Flaxman AD, Wiersma ST (2013) Global epidemiology of hepatitis $C$ virus infection: new estimates of age-specific antibody to HCV seroprevalence. Hepatol Baltim Md 57:1333-1342. https:// doi.org/10.1002/hep.26141

4. Amer F, Yousif M (2015) Epidemiology of hepatitis C virus infection in Egypt. Int J Trop Dis Health 7:119-131. https://doi.org/10.9734/IJTDH/2015/15727

5. Kandeel A, Genedy M, El-Refai S et al (2017) The prevalence of hepatitis $C$ virus infection in Egypt 2015: implications for future policy on prevention and treatment. Liver Int 37:45-53. https://doi.org/10.1111/liv.13186

6. Cuadros DF, Branscum AJ, Miller FD, Abu-Raddad $\sqcup$ (2014) Spatial epidemiology of hepatitis C virus infection in Egypt: analyses and implications. Hepatol Baltim Md 60:1150-1159. https://doi.org/10.1002/hep.27248

7. Bowen DG, Walker CM (2005) Adaptive immune responses in acute and chronic hepatitis C virus infection. Nature 436:946-952. https://doi.org/10. 1038/nature04079

8. Maasoumy B, Wedemeyer H (2012) Natural history of acute and chronic hepatitis C. Best Pract Res Clin Gastroenterol 26:401-412. https://doi.org/10. 1016/j.bpg.2012.09.009

9. Uto H, Mawatari S, Kumagai K et al (2012) Clinical features of hepatitis C virus carriers with persistently normal alanine aminotransferase levels. Hepat Mon 12:77-84. https://doi.org/10.5812/hepatmon.829

10. Leandro G, Mangia A, Hui J et al (2006) Relationship between steatosis, inflammation, and fibrosis in chronic hepatitis C: a meta-analysis of individual patient data. Gastroenterology 130:1636-1642. https://doi.org/10. 1053/j.gastro.2006.03.014
11. Lapa D, Garbuglia AR, Capobianchi MR, Del Porto P (2019) Hepatitis C virus genetic variability, human immune response, and genome polymorphisms: Which Is the Interplay? Cells 8. https://doi.org/10.3390/cells8040305

12. Modi AA, Liang TJ (2008) Hepatitis C: a clinical review. Oral Dis 14:10-14. https://doi.org/10.1111/j.1601-0825.2007.01419.x

13. Dimitrova M, Imbert I, Kieny MP, Schuster C (2003) Protein-protein interactions between hepatitis C virus nonstructural proteins. J Virol 77 : $5401-5414$

14. Scott JD, Gretch DR (2007) Molecular diagnostics of hepatitis C virus infection: a systematic review. JAMA 297:724-732. https://doi.org/10.1001/ jama.297.7.724

15. Martinot-Peignoux M, Boyer N, Cazals-Hatem D et al (2001) Prospective study on anti-hepatitis $C$ virus-positive patients with persistently normal serum alanine transaminase with or without detectable serum hepatitis C virus RNA. Hepatol Baltim Md 34:1000-1005. https:/doi.org/10.1053/jhep.2001.28458

16. Puoti C, Castellacci R, Montagnese F et al (2002) Histological and virological features and follow-up of hepatitis $C$ virus carriers with normal aminotransferase levels: the Italian prospective study of the asymptomatic $C$ carriers (ISACC). J Hepatol 37:117-123

17. Ghouri YA, Mian I, Rowe JH (2017) Review of hepatocellular carcinoma: epidemiology, etiology, and carcinogenesis. J Carcinog 16. https://doi.org/ 10.4103/jcar.JCar_9_16

18. Toosi AEK (2015) Liver fibrosis: causes and methods of assessment, a review. Romanian J Intern Med Rev Roum Med Interne 53:304-314. https://doi.org/ 10.1515/rjim-2015-0039

19. Chen SL, Morgan TR (2006) The natural history of hepatitis C virus (HCV) infection. Int J Med Sci 3:47-52

20. Bedossa P, Poynard T (1996) An algorithm for the grading of activity in chronic hepatitis C. The METAVIR Cooperative Study Group. Hepatol Baltim Md 24:289-293. https://doi.org/10.1002/hep.510240201

21. Poynard T, Ratziu V, Benhamou Y et al (2000) Natural history of HCV infection. Baillieres Best Pract Res Clin Gastroenterol 14:211-228

22. Turhan NK, llikhan SU, Hamamcioglu AC et al (2015) Angiotensin-converting enzyme gene polymorphism (insertion/deletion) and liver fibrosis in Turkish patients from the western Black Sea region, Turkey. Genet Mol Res GMR 14: 17079-17090. https://doi.org/10.4238/2015.December.16.8

23. Ballester JM, Rivero RA, Villaescusa R et al (2005) Hepatitis C virus antibodies and other markers of blood-transfusion-transmitted infection in multitransfused Cuban patients. J Clin Virol Off Publ Pan Am Soc Clin Virol 34(Suppl 2):S39-S46. https://doi.org/10.1016/s1386-6532(05)80033-2

24. Elgharably A, Gomaa Al, Crossey MM et al (2016) Hepatitis C in Egypt-past, present, and future. Int J Gen Med 10:1-6. https://doi.org/10.2147/JGGM. S119301

25. Lybeck C, Brenndörfer ED, Sällberg M et al (2019) Long-term follow-up after cure from chronic hepatitis $C$ virus infection shows occult hepatitis and a risk of hepatocellular carcinoma in noncirrhotic patients. Eur J Gastroenterol Hepatol 31:506-513. https://doi.org/10.1097/MEG.0000000000001316

26. Powell EE, Edwards-Smith CJ, Hay JL et al (2000) Host genetic factors influence disease progression in chronic hepatitis C. Hepatol Baltim Md 31: 828-833. https://doi.org/10.1053/he.2000.6253

27. Akuta N, Kobayashi M, Suzuki F et al (2016) Liver fibrosis and body mass index predict hepatocarcinogenesis following eradication of hepatitis $C$ virus RNA by direct-acting antivirals. Oncology 91:341-347. https://doi.org/ $10.1159 / 000450551$

28. Cholet F, Nousbaum J-B, Richecoeur M, et al (2008) Factors associated with liver steatosis and fibrosis in chronic hepatitis C patients. /data/revues/ 03998320/00280003/272/

29. Hu K-Q, Kyulo NL, Esrailian E et al (2004) Overweight and obesity, hepatic steatosis, and progression of chronic hepatitis $\mathrm{C}$ : a retrospective study on a large cohort of patients in the United States. J Hepatol 40:147-154. https:// doi.org/10.1016/S0168-8278(03)00479-3

30. Massard J, Ratziu V, Thabut D et al (2006) Natural history and predictors of disease severity in chronic hepatitis C. J Hepatol 44:S19-S24. https://doi.org/ 10.1016/j.jhep.2005.11.009

31. Ratziu V, Giral P, Charlotte F et al (2000) Liver fibrosis in overweight patients Gastroenterology 118:1117-1123. https://doi.org/10.1016/S00165085(00)70364-7

32. Yen Y-H, Chang K-C, Tsai M-C et al (2018) Elevated body mass index is a risk factor associated with possible liver cirrhosis across different etiologies of chronic liver disease. J Formos Med Assoc 117:268-275. https://doi.org/10 1016/j.jfma.2017.09.002 
33. Villa E, Vukotic R, Cammà C et al (2012) Reproductive status is associated with the severity of fibrosis in women with hepatitis C. PLOS ONE 7:e44624. https://doi.org/10.1371/journal.pone.0044624

34. Chen G, Cheung R, Tom JW (2017) Hepatitis: sedation and anesthesia implications. Anesth Prog 64:106-118. https://doi.org/10.2344/anpr-64-02-13

35. Carvalho JR, Machado MV (2018) New insights about albumin and liver disease. Ann Hepatol 17:547-560. https://doi.org/10.5604/01.3001.0012.0916

36. Kotoh K, Fukushima M, Horikawa Y et al (2012) Serum albumin is present at higher levels in alcoholic liver cirrhosis as compared to HCV-related cirrhosis. Exp Ther Med 3:72-75. https://doi.org/10.3892/etm.2011.370

37. Lee JS (2012) Albumin for end-stage liver disease. Korean J Intern Med 27: 13-19. https://doi.org/10.3904/kjim.2012.27.1.13

38. Nagao Y, Sata M (2010) Serum albumin and mortality risk in a hyperendemic area of HCV infection in Japan. Virol J 7:375. https://doi.org/ $10.1186 / 1743-422 X-7-375$

39. Valerio C, Theocharidou E, Davenport A, Agarwal B (2016) Human albumin solution for patients with cirrhosis and acute on chronic liver failure: beyond simple volume expansion. World J Hepatol 8:345-354. https://doi. org/10.4254/wjh.v8.17.345

40. Metwalley KA, Sherif T (2014) Thyroid functions and autoimmunity in Egyptian children with chronic hepatitis $C$ virus infection before interferon treatment. Thyroid Res Pract 11:103. https://doi.org/10.4103/0973-0354.138554

41. Rodríguez-Torres M, Ríos-Bedoya CF, Ortiz-Lasanta G et al (2008) Thyroid dysfunction (TD) among chronic hepatitis $C$ patients with mild and severe hepatic fibrosis. Ann Hepatol 7:72-77

42. Chang Y-K, Tseng Y-T, Chen K-H, Chen K-T (2019) Long-term outcomes and risk factors of thyroid dysfunction during pegylated interferon and ribavirin treatment in patients with chronic hepatitis C infection in Taiwan. BMC Endocr Disord 19:36. https://doi.org/10.1186/s12902-019-0362-7

43. Halbrecht I, Klibanski C (1956) Identification of a new normal embryonic hæmoglobin. Nature 178:794-795. https://doi.org/10.1038/178794a0

44. Bayati N, Silverman AL, Gordon SC (1998) Serum alpha-fetoprotein levels and liver histology in patients with chronic hepatitis C. Am J Gastroenterol 93:2452-2456. https://doi.org/10.1016/S0002-9270(98)00584-X

45. Mousa N, Gad Y, Abdel-Aziz A, Abd-Elaal I (2012) Increased a-fetoprotein predicts steatosis among patients with chronic hepatitis C genotype 4. Int J Hepatol 2012. https://doi.org/10.1155/2012/636392

46. Dayan S, Dal T, Tekin R et al (2017) Non-invasive parameters in the assessment of liver fibrosis. Biomed Res 28

47. Das RN, Mukherjee S, Sharma I (2018) Alkaline phosphatase determinants of liver patients. JOP J Pancreas 19

48. ljaz B, Ahmad W, Javed FT et al (2011) Association of laboratory parameters with viral factors in patients with hepatitis C. Virol J 8:361. https://doi.org/10. 1186/1743-422X-8-361

49. Attallah AM, Shiha GE, Omran MM, Zalata KR (2006) A discriminant score based on four routine laboratory blood tests for accurate diagnosis of severe fibrosis and/or liver cirrhosis in Egyptian patients with chronic hepatitis C. Hepatol Res 34:163-169. https://doi.org/10.1016/j.hepres.2005.12.004

50. Wai C-T, Greenson JK, Fontana RJ et al (2003) A simple noninvasive index can predict both significant fibrosis and cirrhosis in patients with chronic hepatitis C. Hepatology 38:518-526. https://doi.org/10.1053/jhep.2003.50346

51. María García-Montalvo B, Luis Galguera-Colorado P (2008) Distribution of hepatitis $C$ virus genotypes, risk factors and liver disease in patients from Yucatán, México: Original Article. Ann Hepatol 7:345-349. https://doi.org/10. 1016/S1665-2681(19)31835-6

52. Missiha SB, Ostrowski M, Heathcote EJ (2008) Disease progression in chronic hepatitis C: modifiable and nonmodifiable factors. Gastroenterology 134 1699-1714. https://doi.org/10.1053/j.gastro.2008.02.069

53. Ohishi W, Fujiwara S, Cologne JB et al (2008) Risk factors for hepatocellular carcinoma in a Japanese population: a nested case-control study. Cancer Epidemiol Prev Biomark 17:846-854. https://doi.org/10.1158/1055-9965.EPI-07-2806

54. Vranjkovic A, Deonarine F, Kaka S et al (2019) Direct-acting antiviral treatment of HCV infection does not resolve the dysfunction of circulating CD8+ T-cells in advanced liver disease. Front Immunol 10. https://doi.org/ 10.3389/fimmu.2019.01926

55. Gicquelais RE, Foxman B, Coyle J, Eisenberg MC (2019) Hepatitis C transmission in young people who inject drugs: insights using a dynamic model informed by state public health surveillance. Epidemics 27:86-95. https://doi.org/10.1016/j.epidem.2019.02.003
56. Espinosa C, Jhaveri R, Barritt AS (2018) Unique challenges of hepatitis C in infants, children, and adolescents. Clin Ther 40:1299-1307. https://doi.org/ 10.1016/j.clinthera.2018.07.010

57. Prussing C, Bornschlegel K, Balter S (2015) Hepatitis C surveillance among youth and young adults in New York City, 2009-2013. J Urban Health Bull N Y Acad Med 92:387-399. https://doi.org/10.1007/s11524-014-9920-5

58. Narciso-Schiavon JL, de Lucca Schiavon L, Carvalho-Filho RJ et al (2010) Gender influence on treatment of chronic hepatitis C genotype 1. Rev Soc Bras Med Trop 43:217-223. https://doi.org/10.1590/S0037-86822010000300001

59. Ahmad W, ljaz B, Javed FT et al (2011) A comparison of four fibrosis indexes in chronic HCV: development of new fibrosis-cirrhosis index (FCI). BMC Gastroenterol 11:44. https://doi.org/10.1186/1471-230X-11-44

60. Moliner LD, Pontisso P, Salvo GLD et al (1998) Serum and liver HCV RNA levels in patients with chronic hepatitis C: correlation with clinical and histological features. Gut 42:856-860. https://doi.org/10.1136/gut.42.6.856

61. Huang D, Lin T, Wang $S$ et al (2019) The liver fibrosis index is superior to the APRI and FIB-4 for predicting liver fibrosis in chronic hepatitis B patients in China. BMC Infect Dis 19:878. https://doi.org/10.1186/s12879-019-4459-4

62. Sheen $V$, Nguyen $H$, Jimenez $M$ et al (2016) Routine laboratory blood tests may diagnose significant fibrosis in liver transplant recipients with chronic hepatitis C: a 10 year experience. J Clin Transl Hepatol 4:20-25. https://doi. org/10.14218/JCTH.2015.00034

63. Vagu C, Sultana C, Ruta S (2013) Serum iron markers in patients with chronic hepatitis C infection. Hepat Mon 13:e13136. https://doi.org/10.5812/ hepatmon.13136

64. Pan Y, Muheremu A, Wu X, Liu J (2016) Relationship between platelet parameters and hepatic pathology in patients with chronic hepatitis $B$ infection-a retrospective cohort study of 677 patients. J Int Med Res 44: 779-786. https://doi.org/10.1177/0300060516650076

65. El-Hawary MA, El-Raziky MS, Esmat G et al (2007) Assessment of hepatic fibrosis in pediatric cases with hepatitis C virus in Egypt. World J Gastroenterol: WJG 13:2846-2851. https://doi.org/10.3748/wjg.v13.i20.2846

\section{Publisher's Note}

Springer Nature remains neutral with regard to jurisdictional claims in published maps and institutional affiliations.

\section{Submit your manuscript to a SpringerOpen ${ }^{\circ}$ journal and benefit from:}

- Convenient online submission

- Rigorous peer review

- Open access: articles freely available online

High visibility within the field

- Retaining the copyright to your article

Submit your next manuscript at $>$ springeropen.com 